\title{
Pyrimidine Dimer Excision Repair of DNA in Bacteroides fragilis Wild-type and Mitomycin C-sensitive/UV-sensitive Mutants
}

\author{
By VALERIE R. ABRATT, ${ }^{1}$ GEORGE L. LINDSAY ${ }^{2}$ AND \\ DAVID R. WOODS ${ }^{1 *}$ \\ ${ }^{1}$ CSIR Microbial Genetics Research Unit, Department of Microbiology and ${ }^{2}$ Department of \\ Biochemistry, University of Cape Town, Rondebosch 7700, South Africa
}

(Received 31 December 1985; revised 21 April 1986)

\begin{abstract}
An enzyme preparation purified from Micrococcus luteus was shown to be specific for UVinduced pyrimidine dimers and was suitable for the detection of DNA excision repair systems. The wild-type Bacteroides fragilis Bf-2 strain and a mitomycin C-sensitive mutant (MTC25) had constitutive dimer excision systems which functioned efficiently under anaerobic and aerobic conditions. A UV-sensitive mutant (UVS9) had markedly reduced levels of the constitutive dimer excision systems under anaerobic and aerobic conditions. Since liquid holding recovery under aerobic conditions was inhibited by chloramphenicol whereas the final level of excision repair in $B$. fragilis $\mathbf{B f}-2$ was not affected, it is concluded that pyrimidine dimer removal is not the process responsible for increased physiological aerobic liquid holding recovery.
\end{abstract}

INTRODUCTION

The repair of DNA damage in Bacteroides fragilis is interesting in that survival after far-UV irradiation $(254 \mathrm{~nm})$ is affected by $\mathrm{O}_{2}$ (Jones et al., 1980; Jones \& Woods, 1981; Slade et al., 1981). Furthermore, novel $\mathrm{O}_{2}-$ and $\mathrm{H}_{2} \mathrm{O}_{2}$-induced phage reactivation systems have been reported for $B$. fragilis (Slade et al., 1983a,b). The physiological responses of $B$. fragilis to UV damage have been investigated (Jones et al., 1980; Jones \& Woods, 1981; Slade et al., 1981 ; Schumann et al., 1982), but the molecular mechanisms for repair of UV-irradiated DNA in this organism are unknown. We recently reported the isolation and physiological characterization of mitomycin C-sensitive mutants in B. fragilis (Abratt et al., 1985). One mutant (MTC25) was markedly sensitive to mitomycin $C$ but had the same UV sensitivity as the wild-type; another mutant (UVS9) was sensitive to UV radiation but was only moderately sensitive to mitomycin C. We have investigated the excision repair capabilities of these mutants and the wild-type strain using the dimer-specific Micrococcus luteus UV endonuclease enzyme to detect the presence of pyrimidine dimers.

\section{METHODS}

Bacteria. The B. fragilis wild-type strain (Bf-2), and mitomycin C-sensitive (MTC25) and UV-sensitive (UVS9) mutants of this strain, were utilized; they have been described previously (Abratt et al., 1985).

Media. Difco brain heart infusion broth and agar supplemented with haemin, menadione and cysteine (Holderman \& Moore, 1972) were used for bacterial growth at $37^{\circ} \mathrm{C}$. Anaerobic and aerobic one-quarter-strength Ringer's solutions were used as dilution buffers. All anaerobic manipulations were done under stringent anaerobic conditions in an anaerobic glove cabinet (Forma Scientific) in an atmosphere of $75 \% \mathrm{~N}_{2}, 20 \% \mathrm{CO}_{2}$ and $5 \% \mathrm{H}_{2}$.

UV irradiation. Methods for irradiating cells under aerobic and anaerobic conditions were as described previously (Jones \& Woods, 1981).

Purification of $U V$ endonuclease from $M$. luteus. This was done by a modification of the methods of Grafstrom et al. (1982) and Hays et al. (1985). The crude $M$. luteus extract (fraction A of Grafstrom et al., 1982) was loaded onto an Affi-Gel Blue (Biorad) column, bed volume $50 \mathrm{ml}$, equilibrated with $0.3 \mathrm{M}-\mathrm{NaCl}$ in buffer containing $20 \mathrm{mM}$ Tris $/ \mathrm{HCl}, \mathrm{pH} 8 \cdot 0,1 \mathrm{~mm}-\mathrm{EDTA}, 1 \mathrm{mM}-2$-mercaptoethanol and $10 \%(\mathrm{v} / \mathrm{v})$ glycerol. The column was washed 
stepwise with this buffer, first containing $0.3 \mathrm{M}-\mathrm{NaCl}$, then $1.2 \mathrm{M}-\mathrm{NaCl}$; the enzyme activity was then eluted with $3 \mathrm{M}-\mathrm{NaCl}$. The $\mathrm{NaCl}$ was removed by dialysis and the partially purified endonuclease precipitated with $70 \%(\mathrm{w} / \mathrm{v})$ ammonium sulphate. Storage was at $-20^{\circ} \mathrm{C}$ in $50 \mathrm{~mm}$-HEPES/ $\mathrm{NaOH}, \mathrm{pH} 7 \cdot 6$, containing $100 \mathrm{mg}$ bovine serum albumin $\mathrm{ml}^{-1}, 1 \mathrm{mM}$-dithiothreitol, $0 \cdot 19 \%(\mathrm{v} / \mathrm{v})$ Triton $\mathrm{X}-100$ and $50 \%(\mathrm{v} / \mathrm{v})$ glycerol.

DNA excision repair. Overnight broth cultures of the $B$. fragilis strains were diluted 10 -fold into $10 \mathrm{ml}$ prewarmed broth and grown to mid-exponential phase $\left(A_{600} 0 \cdot 3-0.4\right)$. The cells were harvested anaerobically by centrifugation and resuspended in $10 \mathrm{ml}$ anaerobic or aerobic one-quarter-strength Ringer's solution. The cell suspensions were exposed to a UV dose of $15 \mathrm{~J} \mathrm{~m}^{-2}$ (Jones \& Woods, 1981). Samples were removed either immediately after irradiation or after post-irradiation incubation at $30^{\circ} \mathrm{C}$. The cells were incubated at $30^{\circ} \mathrm{C}$ as previous physiological experiments on liquid holding recovery were done at $30^{\circ} \mathrm{C}$ (Jones \& Woods, 1981). In experiments to determine the effect of chloramphenicol on dimer excision, $10 \mu \mathrm{g}$ chloramphenicol ml ${ }^{-1}$ was added to the cells $15 \mathrm{~min}$ before irradiation and to the holding buffer after irradiation. Cells from $1 \mathrm{ml}$ samples were harvested by centrifugation, resuspended in $0.5 \mathrm{ml}$ cold lysis buffer $(50 \mathrm{~mm}-\mathrm{Tris} / \mathrm{HCl}, \mathrm{pH} 8.0,10 \mathrm{mM}-\mathrm{Na}-\mathrm{EDTA}$, $500 \mathrm{~mm}-\mathrm{NaCl}$ ), and lysed at $4{ }^{\circ} \mathrm{C}$ for $10-15 \mathrm{~min}$ by the addition of SDS to a final concentration of $1 \%(\mathrm{w} / \mathrm{v})$. The DNA was extracted with phenol and precipitated with $99 \%(v / v)$ ethanol during overnight storage at $-20^{\circ} \mathrm{C}$. The precipitate was pelleted by centrifugation and resuspended in $100 \mu$ l endonuclease buffer (Campbell \& Yasbin, 1984). Repair of UV damage was assayed as described by Campbell \& Yasbin (1984) (Fig. 1). The UV endonuclease was diluted $1: 100$ and $2 \mu \mathrm{l}$ was added to $20 \mu \mathrm{lDNA}$. After $1 \mathrm{~h}$ incubation at $37^{\circ} \mathrm{C}$ the entire sample was electrophoresed on a $0.5 \%$ alkaline agarose gel (Maniatis et al., 1982). The ethidium bromide stained gel was photographed using Polaroid negative film. Quantification was done by scanning the negative with a Beckman DU 8 spectrophotometer (Wood, 1985). The amount of high $M_{\mathrm{r}}$ DNA present after the various treatments was related to undigested control samples included in each gel by peak triangulation. High $M_{\mathrm{r}}$ DNA is defined as DNA which is no longer sensitive to incision by $M$. luteus UV endonuclease.

\section{RESULTS AND DISCUSSION}

\section{Preparation of the $M$. luteus dimer specific endonuclease}

Although $B$. fragilis has been shown to incorporate exogenous radiolabelled thymidine into DNA (Schumann et al., 1984), the level of incorporation is insufficient to allow excision repair studies involving radiolabelled thymine dimers at low UV doses. An alternative approach (Campbell \& Yasbin, 1984) using the pyrimidine dimer specific $M$. luteus endonuclease (Riazzudin \& Grossman, 1977) was made to detect the presence of pyrimidine dimers in the UVirradiated DNA. This enzyme makes a single strand cut adjacent to any pyrimidine dimers present in the DNA. If the dimers have been removed by a repair mechanism, the DNA will not be nicked. The enzyme prepared as described was specific for irradiated pBR325 DNA when assayed semi-quantitatively (Hays et al., 1985). A $1 \mu$ l sample of a $1: 100$ dilution of the enzyme (about $0 \cdot 1 \mu \mathrm{g}$ protein; Bradford, 1976) completely relaxed $340 \mathrm{ng}$ supercoiled pBR325 DNA irradiated with a dose of $150 \mathrm{~J} \mathrm{~m}^{-2}$. The enzyme specifically nicked irradiated $B$. fragilis chromosomal DNA; this was detected on the gel as a broad smear of small DNA fragments which sometimes masked the plasmid(s) contained in Bf-2 cells (Fig. 1). The enzyme preparation had no effect on unirradiated $B$. fragilis DNA (Fig. 1) and the chromosomal DNA appeared as a zone of high $M_{\mathrm{r}}$ DNA.

\section{Excision repair of thymine dimers}

Irradiation of the cells at $15 \mathrm{~J} \mathrm{~m}^{-2}$ was chosen for these experiments as this is a convenient low dose falling at the end of the shoulder region of the $B$. fragilis wild-type survival curve. Lower doses $\left(5-15 \mathrm{~J} \mathrm{~m}^{-2}\right)$ gave similar but less easily visualized results on the gels.

The wild-type $B$. fragilis strain was able to remove pyrimidine dimers during holding in buffer under both anaerobic and aerobic conditions (Fig. 1A, Table 1). Immediately after irradiation the chromosomal DNA was nicked by the $M$. luteus dimer specific endonuclease. After $1 \mathrm{~h}$ holding in buffer under aerobic and anaerobic conditions, the DNA was repaired and appeared as a band of high $M_{\mathrm{r}}$ DNA. Densitometer tracings of the gels clearly reflected the gel pictures (Fig. 2). The DNA profiles for nicked and repaired DNA could be easily distinguished and the amount of repair estimated as a percentage of the undigested control of each sample (Table 1). The mitomycin C-sensitive (MTC25) mutant strain also showed dimer removal within $1 \mathrm{~h}$ under aerobic and anaerobic conditions (Figs $1 \mathrm{~B}$ and 2B, Table 1). In comparison with the wild-type, 


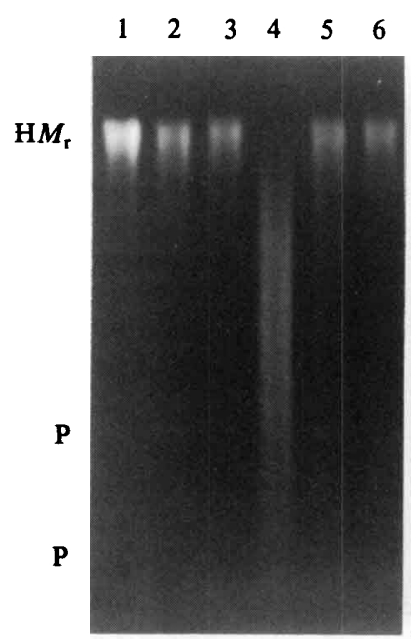

A

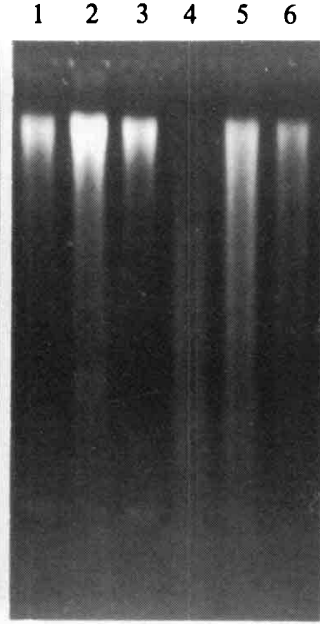

B

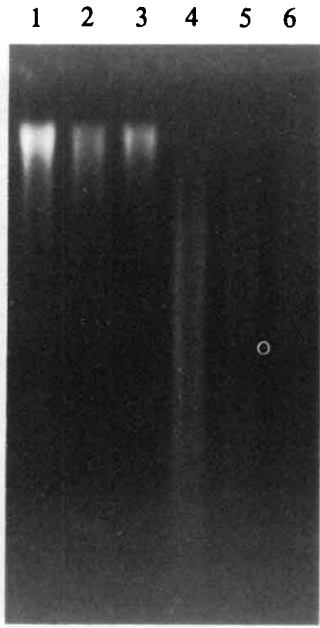

C

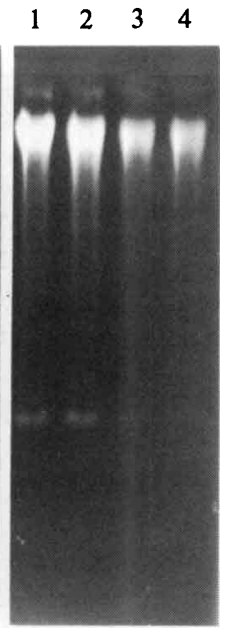

D

Fig. 1. Dimer excision by $B$. fragilis $\mathrm{Bf}-2, \mathrm{MTC} 25$ and UVS9 strains under anaerobic conditions. The presence or absence of dimers in the irradiated DNA was assayed using the dimer specific $M$. luteus UV endonuclease. The enzyme was diluted $1: 100$ and $2 \mu \mathrm{l}$ was added to $20 \mu \mathrm{l} B$. fragilis DNA. After incubation at $37^{\circ} \mathrm{C}$ for $1 \mathrm{~h}$ the entire sample plus $5 \mu$ l alkaline tracking dye was electrophoresed on a $0.5 \%$ alkaline agarose gel. A, wild-type; B, MTC25; C, UVS9; D, wild-type unirradiated control. HM, high $M_{\mathrm{r}}$ chromosomal DNA; $\mathrm{P}$, plasmid DNA.

Key:

$$
\begin{aligned}
& \text { UV }\left(15 \mathrm{~J} \mathrm{~m}^{-2}\right) \\
& \text { *HT } \\
& \text { Endonuclease }
\end{aligned}
$$

\begin{tabular}{|c|c|c|c|c|c|c|c|c|c|c|}
\hline \multirow[b]{2}{*}{ Lane ... } & \multicolumn{6}{|c|}{$A, B$ and $C$} & \multicolumn{4}{|c|}{ D } \\
\hline & 1 & 2 & 3 & 4 & 5 & 6 & 1 & 2 & 3 & 4 \\
\hline & + & + & + & + & + & + & - & - & - & - \\
\hline & 0 & 1 & 2 & 0 & 1 & 2 & 0 & 0 & 2 & 2 \\
\hline & - & - & - & + & + & + & - & + & - & + \\
\hline
\end{tabular}

* HT, Post-irradiation holding time (h).

\section{Table 1. Effect of chloramphenicol on the maximum levels of dimer excision in $B$. fragilis}

Chloramphenicol $(\mathrm{Cm})\left(10 \mu \mathrm{g} \mathrm{ml}^{-1}\right)$ was added $15 \mathrm{~min}$ before irradiation and during holding in buffer under aerobic and anaerobic conditions. The cells were incubated until no further repair took place and the final percentage of high $M_{\mathrm{r}}$ DNA present was determined by triangulation of the peak occurring within $5 \mathrm{~mm}$ from the end of the well (Fig. 2). The amount of high $M_{\mathrm{r}}$ DNA in the digested sample after

\begin{tabular}{|c|c|c|c|c|}
\hline \multirow[b]{3}{*}{ Strain } & \multicolumn{4}{|c|}{ High $M_{\mathrm{r}}$ DNA $(\%)$} \\
\hline & \multicolumn{2}{|c|}{ Anaerobic } & \multicolumn{2}{|c|}{ Aerobic } \\
\hline & $-\mathrm{Cm}$ & $+\mathrm{Cm}$ & $-\mathrm{Cm}$ & $+\mathrm{Cm}$ \\
\hline $\begin{array}{l}\text { Wild-type } \\
\text { MTC25 } \\
\text { UVS9 }\end{array}$ & $\begin{array}{l}81-100 \\
52-69 \\
16-30\end{array}$ & $\begin{array}{l}85-100 \\
46-73 \\
18-31\end{array}$ & $\begin{array}{l}84-98 \\
94-100 \\
20-48\end{array}$ & $\begin{array}{l}91-94 \\
90-100 \\
33-43\end{array}$ \\
\hline
\end{tabular}
the various treatments was expressed as a percentage of its undigested control. The range of results obtained in four experiments is given.

the MTC25 mutant showed slightly lower levels of dimer removal under anaerobic conditions. The UV-sensitive (UVS9) mutant showed very much reduced dimer removal under both aerobic and anaerobic conditions (Figs $1 \mathrm{C}$ and $2 \mathrm{C}$, Table 1).

The effect of chloramphenicol on the excision of dimers was determined by the addition of $10 \mu \mathrm{g}$ chloramphenicol $\mathrm{ml}^{-1} 15 \mathrm{~min}$ before irradiation and during holding in buffer under anaerobic and aerobic conditions. Schumann et al. (1984) showed that this concentration of 

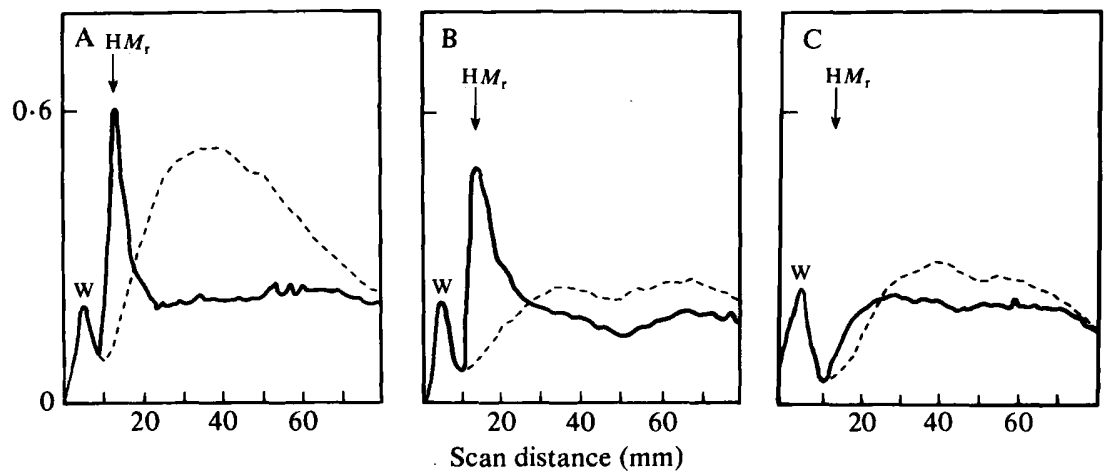

Fig. 2. Densitometer tracing of alkaline agarose gels shown in Fig. 1. A, wild-type; B, MTC25; C, UVS9. The ethidium bromide stained gels were photographed using Polaroid negative film and scanned with a Beckman DU8 spectrophotometer. ---, $0 \mathrm{~h}$ post-irradiation holding time (lane 4, Fig. 1.); - 2 h post-irradiation holding time (lane 6, Fig. 1). H $M_{r}$, high $M_{r}$ chromosomal DNA; W, gel well.

chloramphenicol inhibits protein synthesis in this strain. In the presence of chloramphenicol the same maximum level of total repair was ultimately obtained as in the absence of chloramphenicol (Table 1) but it took longer. The rate of repair was approximately halved by chloramphenicol. The rate of repair was also affected by the physiological state of the cells. Cells grown under sub-optimal conditions before irradiation showed slower rates of repair. The addition of chloramphenicol to the holding buffer immediately after irradiation did not affect the rate or final level of repair.

Since dimer excision was not abolished by chloramphenicol it is concluded that there is a constitutive dimer excision system in $B$. fragilis. The decrease in the rate of dimer excision in cells pre-treated with chloramphenicol could be due to either the effect of chloramphenicol on the physiological state of the cells, or to the inhibition of synthesis of another induced dimer excision system which enhanced the rate of repair.

Jones $e$ t al. (1981) reported that liquid holding recovery occurred in $B$. fragilis $\mathrm{Bf}-2$ only under aerobic conditions and that this was completely inhibited by $10 \mu \mathrm{g}$ chloramphenicol ml ${ }^{-1}$ added to the holding buffer immediately after irradiation (Jones, 1979). The results reported here show that dimer excision was not inhibited under these experimental conditions. Removal of pyrimidine dimers from irradiated $B$. fragilis DNA was therefore not the process responsible for increased physiological recovery during aerobic liquid holding. This observation was supported by the fact that dimer excision was found to occur under anaerobic conditions where no physiological liquid holding recovery was observed (Jones et al., 1981). Furthermore, the UVsensitive mutant of $\boldsymbol{B}$. fragilis showed very low levels of dimer excision under aerobic conditions $(20-40 \%)$, while maintaining the same level of physiological liquid holding recovery as the wildtype (Abratt et al., 1985). This result differs from that found in Escherichia coli $\mathrm{K} 12$ rec A mutants where dimer excision is essential for liquid holding recovery (Ganesan \& Smith, 1969). The mitomycin C-sensitive mutant showed slightly reduced levels of dimer excision compared with the wild-type under anaerobic conditions $(50-70 \%)$ in spite of having wild-type resistance to $U V$. This suggests that dimer removal is not the only repair system functional in $B$. fragilis. The UV-sensitive mutant was not totally deficient in repair. It retained a low level of excision repair and had a residual shoulder (indicating repair) in the UV survival curve at low UV doses (Abratt et al., 1985). The low level of repair in the UVS9 mutant could be interpreted as either evidence for a second repair system or, alternatively, the mutant has a leaky mutation and excision repair is only reduced. However the chloramphenicol experiments indicate that $\boldsymbol{B}$. fragilis possesses at least two UV repair systems; a constitutive dimer excision mechanism, and a further, as yet unidentified, cellular response. 
D.R.W. and V.R.A. acknowledge research grants from the South African Council for Scientific and Industrial Research.

\section{REFERENCES}

AbraTt, V. R., Jones, D. T. \& WoOds, D. R. (1985). Isolation and physiological characterization of mitomycin C-sensitive/UV-sensitive mutants in Bacteroides fragilis. Journal of General Microbiology 131, 2479-2483.

BRADFORD, M. M. (1976). A rapid and sensitive method for the quantitation of microgram quantities of protein utilizing the principle of protein-dye binding. Analytical Biochemistry 72, 248-254.

Campbell, L. A. \& Yasbin, R. E. (1984). A DNA excision repair system for Neisseria gonorrhoeae. Molecular and General Genetics 193, 561-563.

GANESAN, A. K. \& SMITH, K. C. (1969). Dark recovery processes in Escherichia coli irradiated with UV light. II. Effects of uvr genes on liquid holding recovery. Journal of Bacteriology 97, 1129-1133.

Grafstrom, R. H., Park, L. \& Grossman, L. (1982). Enzymatic repair of pyrimidine dimer-containing DNA. Journal of Biological Chemistry 257, 1346513474.

Hays, J. B., Martin, S. J. \& Bhatia, K. (1985). Repair of nonreplicating UV-irradiated DNA: cooperative dark repair by Escherichia coli Uvr and $\mathrm{Phr}$ functions. Journal of Bacteriology 161, 602-608.

Holderman, L. V. \& MoORe, W. E. C. (editors) (1972). Anaerobe Laboratory Manual, 4th edn. Backsburg, Va.: Virginia Polytechnic Institute and State University Anaerobe Laboratory.

JONES, D. T. (1979). Genetic and UV studies on Bacteroides fragilis. PhD thesis, Rhodes University, Grahamstown, South Africa.

JONES, D. T. \& WoODS, D. R. (1981). Effect of oxygen on liquid holding recovery of Bacteroides fragilis. Journal of Bacteriology 145, 1-7.

JoNES, D. T., RoBB, F. T. \& WoODS, D. R. (1980). Effect of oxygen on Bacteroides fragilis survival after far ultraviolet irradiation. Journal of Bacteriology 144, 1179-1181.

Maniatis, T., Fritsch, E. F. \& Sambrook, J. (1982). Molecular Cloning: A Laboratory Manual. Cold Spring Harbor, NY: Cold Spring Harbor Laboratory.

Riazuddin, S. \& Grossman, L. (1977). Micrococcus luteus correndonuclease II: mechanism of action of two endonucleases specific for DNA containing pyrimidine dimers. Journal of Biological Chemistry 252, 6287-6293.

SchumanN, J. P., Jones, D. T. \& WoOds, D. R. (1982). UV light induction of proteins in Bacteroides fragilis under anaerobic conditions. Journal of Bacteriology 151, 44-47.

Schumann, J. P., Jones, D. T. \& Woods, D. R. (1984). Effect of UV irradiation on macromolecular synthesis and colony formation in Bacteroides fragilis. Journal of General Microbiology 130, 771-777.

Slade, H. J. K., Jones, D. T. \& Woods, D. R. (1981). Effect of oxygen radicals and peroxide on survival after ultraviolet irradiation and liquid holding recovery of Bacteroides fragilis. Journal of Bacteriology 147, 685-687.

Slade, H. J. K., Schumann, J. P., Jones, D. T. \& Woods, D. R. (1983a). Peroxide inducible phage reactivation in Bacteroides fragilis. FEMS Microbiology Letters 20, 401-405.

Slade, H. J. K., Schumann, J. P., Parker, J. R., JoNES, D. T. \& WoODS, D. R. $(1983 b)$. Effect of oxygen on host cell reactivation in Bacteroides fragilis. Journal of Bacteriology 153, 1545-1547.

Woods, D. R. (1985). Pyrimidime dimers are not the principal pre-mutagenic lesions induced in lambda phage DNA by ultraviolet light. Journal of Molecular Biology 184, 577-585. 